\title{
The lingering environmental impact of repressive governance: the environmental legacy of the apartheid-era for the new South Africa
}

\author{
Phia Steyn \\ Department of History, University of Stirling
}

\begin{abstract}
This article aims to explore the historical link between contemporary environmental problems and the environmental, economic and political policies of the apartheid government. The analysis draws on an examination of the detrimental environmental impacts of the apartheid-era and how international isolation impacted on governmental environmental management in the country, before turning attention to the way in which the ANC government has managed the South African natural and human environments in the period after 1994. This article shows that despite many important new developments since 1994, that there are high levels of continuity between the environmental management practices of the old and the new regimes. This state of affairs negatively impacts on the ability of the ANC government to provide every South African citizen with the clean and safe environmental guaranteed to all within the 1996 Bill of Rights.
\end{abstract}

\section{Introduction}

The first State of the Environment Report, published by the Department of Environmental Affairs and Tourism in November 1999, paints a sombre picture about the health of the South African environment. The Report points out that while South Africa have the third largest plant and animal biodiversity in the world, the country has the highest extinction rate of plant and animal species on the globe. By 1999, 3,435 plant species, 102 bird species, 72 reptile species, twelve amphibian species, 142 butterfly species and 90 mammal species were listed as threatened in the South African Red Data Books. In 
addition it reported abnormally high air pollution levels in some parts of the country, the generation of too much waste to be disposed off in a proper and safe manner, the disposal of hazardous waste untreated, widespread soil erosion and high levels of water pollution to name but a few (Department of Environmental Affairs and Tourism 1999; Die Volksblad 1999).

The unhealthy state of the South African environment came as no surprise to those actively involved in environment-related activities in the country, especially those involved in documenting the deterioration of the environment over a prolonged period. Truth is, like elsewhere in the world, the South African environment had slowly degraded over the past few decades and many of the present-day environmental problems have roots that go back many years and then especially to the apartheid era. The historical link between contemporary environmental problems and the environmental, economic and political policies of the apartheid government has ensured that the environmental impact of apartheid lingered on long after the establishment of a multiracial, democratic South Africa in 1994. The 1999 State of the Environment Report offers plenty of proof in this regard.

This article aims at exploring the environmental legacy of the apartheid-era for the socalled New South Africa by focusing on the some of the main environmental impacts of apartheid-era policies, and governmental environmental management in the new South Africa. An in-depth analysis of all the relevant areas in which apartheid policies impacted negatively on the South African environment and of environment-related changes in the new South Africa is beyond the scope of this article. Much rather, the article will focus on the main issues and will in particular aim to identify areas in which there have been continuity in the environmental policies and practices pursued by both the old and the new regimes, and also to identify important changes that occurred and progress that has been made by the post-apartheid government in terms of environmental management.

\section{Environment in apartheid South Africa}


The apartheid era in South Africa dates back to 1948 when the National Party (NP) came to power under the leadership of Dr D.F. Malan. The NP had offered voters their policy of apartheid as opposed to existing segregationist policies of the United Party to address what was perceived by the white electorate as the 'native problem'. As the decolonization process in the European colonial empires gained momentum in the 1950s and 1960s so did international opposition to the NP's apartheid policy and the country's continued governance over Namibia. Consequently, the country was increasingly isolated on international political, economic, cultural and sporting levels from the 1960s onwards that included expulsion from the Commonwealth (1961), the International Olympic Committee (1964) and the General Assembly of the United Nations (1974).

International isolation had important repercussions for the development of governmental environmental management in the country especially given the fact that it started at a time when governments around the world started to pay constructive attention to environmental issues on both international and national political levels. South Africa, for example, did not participate in the preparatory processes for the 1972 United Nations Conference on the Human Environment (Stockholm, June 1972), and made almost no contribution to the debates at the conference beyond protesting the condemnation of apartheid in the Declaration on the Human Environment (Principle 1) and opposing a total ban on commercial whaling (as the then third largest whaling nation in the world). In addition, South Africa was not invited to become a member of the Governing Council of the United Nations Environment Programme (UNEP) in 1973 and played no active part in UNEP before 1994 (United Nations 1972; The Star 1972; Rautenbach 1973; Wiley 1986)

An important consequence of the exclusion of South Africa from global environmental initiatives was the fact that the government failed to stay in touch with important changes that occurred both on an international level, and within national environmental governance in other countries. On an international level, the government's inability to identify major paradigm shifts in the management of the natural environment became evident when it started to promote the aims of the World Conservation Strategy (WCS, 
1980) in 1987 (Republic of South Africa 1988). By that time, however, the Strategy had become outdated and had been replaced by the influential Brundtland report, Our common future (1987), as the most important document on the natural environment and the management thereof. The South African government thus opted for an environmental strategy (the WCS) in 1987 that was outdated, while the rest of the world, in response to Our common future, began to take the first tentative steps towards preparing for the implementation of sustainable development policies.

The inability to identify the shift towards sustainable development was greatly influenced by increased attempts to isolate the country internationally in the 1980 s, especially after the disastrous 'Rubicon' speech of State President P.W Botha in August 1985. What little standing the country still had in international environmental circles was shattered in 1987 when acquisitions were aired publicly for the first time in which the South African Defence Force was implicated in an ivory and rhinoceros horn smuggling ring. 1 These factors ensured that South Africa was not invited to participate in the preparatory processes for the 1992 United Nations Conference on Environment and Development (UNCED, Rio de Janeiro, June 1992) and was further denied official representation at the actual event. UNCED also emphasised the lack of legitimacy of the apartheid government on international levels in that it invited official delegations from the African National Congress and the Pan-Africanist Congress to the official proceedings, which delegations were also granted the opportunity to address the conference as a whole. The absence of governmental participation in the UNCED process ensured that the South African government failed to grasp both the future importance of sustainable development and the essence of this developmental model. The fact that South Africa's country report submitted to UNCED failed to integrate environmental and development issues reflects the limited understanding within environment-related governmental structures of sustainable development, and this remained the case until the first democratic elections of April 1994 brought the African National Congress to power (Wynberg 1993; Van der Merwe 1992; Republic of South Africa 1992). 
Domestically, isolation coupled with strong governmental reaction to the anti-apartheid movement ensured that the government resisted all attempts by the environmental nongovernmental organisation (ENGO) sector to politicise the South African environmental movement. Up till the establishment of Earthlife Africa in 1988, the South African environmental movement was characterised by its a-political and conservation-focused nature in which very good relations between the vast majority of the ENGOs and the government were in the order of the day (Cock 1991; Steyn and Wessels 2000). The apolitical nature of the South African environmental movement prior to 1988 ensured that the government was slow to follow global trends in environment-related managerial and legal developments on a national level. A dedicated Department for Environment Affairs, for example, was only established in 1984 after several attempts to pair environmental issues with other state departments failed. The most notorious and damaging pairing was also the very first which occurred in 1973 when the government placed environmental issues within the Department of Planning. The newly named Department of Planning and the Environment lasted until 1979 and, given the key role the Department played in apartheid planning and zoning, ensured that environmental issues came to be associated closely with the implementation of apartheid policies by the anti-apartheid movement (Steyn 2001; Rautenbach 1972).

Not only did the South African government failed to establish a strong, centralised governmental department for environmental issues, but it also failed to pass broadranging environmental legislation. While environmental issues were regulated by an impressive list of acts that either directly or indirectly related to the environment, and which ensured that almost all state departments were involved with environmental legislation in some way or another, broad-ranging environmental legislation were considered unnecessary until the 1980s. After a feeble attempt at this in the form of the 1982 Environment Conservation Act (no 100), the first proper piece of general environmental legislation passed in the country only followed in 1989 with the passing of the Environment Conservation Act (no 73). This act constituted a major milestone in the development of South African environmental law in that it provided, for the first time, for the effective protection and controlled utilisation of the South African environment. It 
also allowed for greater powers for the Minister of Environment Affairs to oppose developments and resource exploitation that could possibly harm the human and natural environments. Unfortunately, neither of the two environment affairs ministers that served up till 1994 in the apartheid cabinet used these expanded powers, nor did they take the important step of making environmental impact assessments compulsory (Rabie and Erasmus 1983; Rabie and Fuggle 1992; Rabie 1994; Glazewski 1991).

The resistance from both the government and the ENGO sector to politicise the South African environment during the apartheid era weakened the effectiveness of ENGOs in the country who, in general, opted to co-operate with the government rather than oppose the government in matters that radically affected the natural environment. Consequently, the non-governmental sector of the South African environmental movement continued to focus predominantly on the conservation of fauna and flora, and the conservation of particular areas that were fenced in to ensure the continuation of their existence. These protected areas became symbols of responsible stewardship of the natural environment for the South African government, the National Parks Board, the provincial nature conservancies, a number of ENGOs and a large segment of the white people in the country. However, the management of these areas as separate entities that allowed little interference from outside, ensured that conservation measures remained divorced from the everyday life of the public in general. It was thus very difficult, and almost impossible, to establish an environmental perspective in which humans were seen as being totally dependent on a healthy natural environment in South Africa, and to promote an environmental agenda that included pertinent issues such as pollution control, the unhealthy state of black townships, environmental degradation in the homelands, and the environmental dangers of uncontrolled economic development.

The profoundly detrimental environmental impact that apartheid had on the human and natural environments of all people of colour in South Africa also made it very difficult for these communities to support the dominant environmental agenda in the country. In addition, the government showed very little understanding of the environmental hardship that people of colour had to endure on a daily basis. Indeed, until the Soweto uprisings of 
1976 the government showed no empathy with the environmental concerns of the majority of the country's population. Those environment-related initiatives implemented from 1977 onwards in urban black townships, however, should not be taken as genuine attempts to improve the human and natural environments of some black communities. Much rather these initiatives represent attempts by an apartheid government that was increasingly coming under siege to appease restless black communities bordering white cities and towns in the country.

Apartheid's environmental toll was tremendous on both homelands and on the black townships bordering the edges of white communities. The homeland system in particular hastened the environmental degradation in the Republic through the overpopulation of these areas. By 1980 an estimated 10.5 million black people lived in the homelands that comprised less that 13 per cent of South Africa's total land surface. This in turn meant that the average population density in the homelands was 66 people per $\mathrm{km}^{2}$. The overcrowding of the homelands had a marked influence on the natural environment and directly led to widespread soil erosion. By 1980 in the Ciskei alone 46 per cent of the land was moderately or severely eroded. With an average of two hectares of land per family, and a general lack of capital for essential farming inputs and conservation measures, land in the homelands deteriorated to the point where it could no longer sustain the people who lived on it. Overpopulation coupled with a general lack of electricity and widespread poverty led to the overexploitation of wood fuel resources within the homelands. By 1980 four of the ten homelands were consuming more wood than their land produced each year, and it was projected that if the annual consumption patterns of between $200 \mathrm{~kg}$ and $800 \mathrm{~kg}$ per capita per year continued, the homelands would be stripped of all natural woodland by 2020. By the end of the 1980s, the forests in QwaQwa had disappeared completely.

Homelands, in general, experienced rapid urbanisation with people migrating to urban areas in search of better work opportunities. In most cases there was little infrastructure available to accommodate new arrivals resulting in widespread squatting along the fringes of the urban centres in the homelands. Though the urban areas were better 
developed, both rural and urban areas in the homelands experienced a lack of infrastructural development and by 1990 only 46 per cent of people had access to clean water while only 13 per cent had access to adequate sanitation. The lack of essential services impacted on the health of the people, with mortality by the fifth year being around 50 per cent in the homelands by 1990. Ironically, though overcrowded, the homelands experienced a shortage in labour. The system of migrant workers that existed in the South African economy meant that black men and women in their prime economically productive years, spent the majority of their time outside their homelands working in 'white' South Africa. Labour shortages in practice meant that the development of the homelands was neglected while black men and women of working age helped the South African economy to develop. (Durning 1990; Timberlake 1988; Van der Berg 1985; Cooper 1992; Wisner 1995).

The policy of separate development also found expression in an urban policy that reserved certain areas for certain population groups. The status of black people as 'visitors' to 'white' South Africa meant that little planning and development went into the black townships bordering white communities, especially because black people were in principle not allowed to settle permanently in these areas prior to the 1980s. The resulting racial division in the provision of housing, services and infrastructure ensured a lack of drinking water, waste removal and sanitation services, proper housing and electricity which combined to make townships a hazard for both human health and the natural environment. By 1994, for example, 6.76 million people in the townships had no access to adequate sewage and sanitation systems, while about 2 million of these people still relied on the bucket system for toilets. Around 20 per cent of the people had minimal access to water, with an average of two to three households sharing a water tap in many of the townships bordering the larger cities. Township dwellers in rural South Africa were in general not that fortunate. In the Mhala District in Gazankulu, a water tap was shared on average by 760 people. Lack of proper town planning in black townships resulted in massive housing shortages in these areas, and it is estimated that by 1993 between 5 and 7.7 million people were living in informal housing (i.e. shacks). (Smuts 1995; Durning 1990; Wisner 1995; Cooper 1992; McDonald 1998). 
A general lack of electricity in the township areas played havoc with the natural environment through abnormally high levels of visible air pollution. Open fires and coal stoves fuelled by either coal or wood provided not only energy to prepare food, but also heated the small dwellings in the townships, and leads to high levels of sulphur dioxide $\left(\mathrm{SO}_{2}\right)$ and particulate matter at ground level. According to Cooper (1992: 4) by 1992, township emissions represented 3 per cent of South Africa's national $\mathrm{SO}_{2}$ emissions and 24 per cent of all particulates emitted in the country. While relatively insignificant on a national level, coal-related emissions have proved to be an environmental hazard on a local level in the townships for residents and medical reports show that children residing in Soweto, for example, suffered more asthma and chest colds than children elsewhere in the country. This is due to the high levels of Soweto's particulate air pollution which exceeds World Health Organisation limits for at least a quarter of each year, and then by as much as 100 per cent. Coal was used in South African townships during the apartheid era primarily because the electrification of townships was not considered a government priority. And, even where electrification did take place, coal stoves continued to play an essential part in township life because of the versatility of these stoves. In Soweto, for example, by 1992 about 22 per cent of newly electrified households in townships also continued to use their coal stoves (Durning 1990; Cooper 1992; Clarke 2002).

High levels of air pollution were not confined to black townships. With coal providing around 82 per cent of the country's total energy, the former Eastern Transvaal Highveld (the Ermeloo-Witbank region), in which 80 per cent of all electricity is generated, was subjected to the highest levels of air pollution in the country throughout the year. The twenty coal-fired power stations in the region emitted on average 32.25 tonnes $\mathrm{SO}_{2} / \mathrm{km}^{2}$ which was even higher than the 30 tonnes $\mathrm{SO}_{2} / \mathrm{km}^{2}$ emitted on average in the former German Democratic Republic which was infamous for its abnormally high levels of air pollution (Tyson, Kruger and Louw 1988; Clarke 1991).

Pollution problems were not confined to the electricity generation industry. Indeed, by the late 1980s a number of well-publicised cases of industrial pollution made headlines 
across the country. These included the dumping of toxins in the Vaal River by the SASOL I plant at Sasolburg in 1988, the leaking of poisonous chemicals into the Selati River (which runs through the Kruger National Park) by a phosphate company in 1988, the regular polluting of the Olifants and Crocodile Rivers by toxic heavy metals, phosphate and nitrogen, the caustic soda spill of the Atomic Energy Corporation into the Moganwe Spruit close to the Hartbeespoort Dam in 1991, Sappi's Ngodwana Paper Mill Spill in September 1989 and the mercury pollution at the Thor Chemicals plant at Cato Ridge (The Weekly Mail 1989; Anon 1991; Business Day 1991; Van Eeden 1991; Koch, Cooper and Coetzee 1990). These and other cases of industrial pollution became symbolic of the relatively high levels of industrial environmental neglect and the weak reaction of government to cases of industrial pollution. Sappi, for example, were fined only ZAR 600 for its Ngodwana Paper Mill spill despite the fact that this spill devastated the ecosystems of the Elands and Crocodile Rivers, and killed more than 22 fish species and other forms of animal life in a stretch of river downstream from the mill.

By 1989 the economic crisis that had set in back in 1973 with the Oil Crisis and the corresponding Arab oil embargo and which was exacerbated by economic and technological sanctions, left very little room for the apartheid government to clamp down on industrial pollution. The need to earn foreign currency through the few permitted exports along with the direct involvement of the state in some of the most polluting of industries (e.g. both Iscor and Escom) ensured that the government seldom reacted to even blatant cases of industrial environmental neglect. In addition, by the end of the 1980s the apartheid government had pursued a policy of uncontrolled economic development that excluded any consideration for the environment and the limitations thereof for many decades. International isolation, economic and technological sanctions and the economic crisis merely ensured that this policy remained unchanged at a time when there was real efforts globally to start addressing the environmental problems associated with uncontrolled economic development. Over time this policy had a tremendous impact on the South African human and natural environments through the overexploitation of resources, the slack enforcement of environmental laws, widespread pollution and the establishment of an economic ethic that excluded environmental 
consideration in the name of survival. The economic ethic lingered on long after the end of apartheid and still continues to derail the successful implementation of sustainable development policies in the new South Africa - only now in the name of poverty reduction.

\section{Environmental protection versus poverty reduction in the new South Africa}

The April 1994 elections brought an end to the apartheid-era in South Africa and brought the African National Congress (ANC), headed by Nelson Mandela, to power. Prior to their election victory, the ANC had shown great sensitivity towards environmental issues in their policy documents issued between 1990 and 1994. Already in 1992 the ANC committed itself in their policy document Ready to Govern to the improvement of the living and working conditions of black people in the country in order to realise their goal of establishing a just and equitable society in South Africa. This was followed by the inclusion of the environment as one of the ten basic needs in the pre-election Reconstruction and Development Policy (RDP). The RDP declared that poverty and environmental degradation were closely related and that improvement in living conditions, access to services and land would all contribute to reducing the negative human pressures on the natural environment in the country. Consequently, the preelection RDP document promoted the inclusion of environmental considerations into all decision-making processes. Unfortunately the ANC left their pro-environment position behind shortly after coming to power and the RDP White Paper, published in September 1994, omitted the chapter on environment that was included in the pre-election document. (ANC 1992; ANC 1994).

Due to the inequalities created under the apartheid system the key objective of the RDP and many other governmental initiatives was poverty reduction. Consequently, employment creation became a central aspect of the new economic policy, the Growth, Employment and Redistribution strategy (GEAR), published in June 1996 because the ANC government believe that providing people with jobs are the best way to reduce poverty levels in the country. It is argued that this in turn would counter poverty-related 
environmental problems, which in theory will greatly aid the establishment of sustainable communities around the country. GEAR made no reference to the need to accommodate environmental considerations in central economic and social planning. Indeed, GEAR placed great emphasis on the reduction of state spending, investment incentives, privatisation, the expansion of heavy industries and an increase in the rate of natural resource exploitation in order to stimulate economic growth; areas that constituted a major source of environmental degradation in apartheid South Africa. Consequently the ANC initially continued with apartheid-era policies that promoted economic development with little consideration of the environmental impact thereof (Le Quesne 2000; Fuggle and Rabie 1999).

Instead of incorporating the environment into mainstream economic and social planning, as is expected under sustainable development, the ANC created a separate forum where all stakeholders could meet to discuss environment-related issues. Despite being removed from the central planning processes, the Consultative National Environmental Policy Process (CONNEPP), launched in 1995, was crucial because it was tasked with the radical overhaul of environment-related legislation (as part of a bigger process to rid the country of apartheid legislation). Many new pieces of environmental legislation resulted from the CONNEPP process, most important of which were the National Water Act (no 36 of 1998) and the National Environmental Management Act (no 107 of 1998). Environmental impact assessments also finally became compulsory in 1997, and it is hoped that the much loathed provision in the regulation of air pollution that still allows for best practical means as opposed to polluter pays will finally be abolished in 2005 . An important legal development for all South African citizens was the inclusion of an environmental right into the Bill of Rights adopted with the new constitution in 1996. In terms of this Bill all South Africans have the right to a clean and healthy environment and to have the environment protected for current and future generations (Le Quesne 2000; Fuggle and Rabie 1999; Department of Environmental Affairs and Tourism 2005).

Despite many successful initiatives that ensured that 85 per cent of households in South Africa now have access to clean water and 63 per cent access to sanitation, the ANC 
government has struggled to come to terms with the environmental legacy of the apartheid era. In terms of environmental management, the ANC inherited a governmental structure that is deeply fragmented with environment-related functions being shared by almost all government departments. The fact that the environment was assigned a functional area of concurrent national and provincial legislature and administrative competence by the 1996 Constitution further ensured that environmental management not only remained fragmented on a national level between governmental departments, but is now also fragmented in its provincial application. While the ANC did strengthen the role of the Department of Environmental Affairs and Tourism, it is still a long way from the strong, centralised governmental department so greatly needed for the successful protection of the South African environment. And, as in the apartheid era, government departments tasked with the promotion of economic and industrial development are still actively involved in the implementation of environmental legislation that effectively curtails development processes. The conflict of interest that results from this dual role that state departments such as Trade and Industry, and Minerals and Energy have has not been properly addressed in the New South Africa (The Presidency 2003; Steyn 2001; Fuggle and Rabie 1999; Rossouw and Wiseman 2004).

In addition, the ANC also inherited the industrial pollution problems of the past and initially showed very little enthusiasm for implementing and regulating the brand-new environmental legislation passed in the first ANC term. Ironically in country's submission to the 2002 World Summit on Sustainable Development, the government notes that it has urged crude oil refineries to reduce their pollution levels in order to comply with national emission standards. This report also proudly cites four different examples of industry implementing pollution control measures as examples of 'activities changing unsustainable consumption and production patterns' (Republic of South Africa 2002: 11). Unfortunately these are still isolated cases of addressing the very high pollution levels prevalent in the country and much more still needs to be done. The new state structures, however, did allow for greater transparency and while the government initially proved unwilling to take on big business, the New South Africa created the space for its citizens to take on industries that adversely affected their health and livelihood. One of these 
community-based struggles is the lawsuit against the widespread pollution caused by the manufacturing processes of steel giant Iscor in the Vanderbijl Park district. The inhabitants of Steel Valley, that lies adjacent to the Iscor plant, is currently suing the company for damages to their health and property, caused by the polluting of their groundwater resources, in the Johannesburg High Court. This lawsuit, along with numerous other grievances from Vaal Triangle communities has finally forced the ANC government to address the abnormally high levels of air, water and ground pollution in the region, and the government announced in June 2005 that they will declare this region the first air pollution 'hot spot' in the country on 1 September 2005, which will force the government and industry for the first time to clean up the Vaal Triangle (Department of Environmental Affairs and Tourism 2005; Macleod 2005; Groenewald 2004).

In an important departure from the apartheid era, the ANC did focus on the promotion of social development with the expansion of housing and basic services at the centre of these policies. However, most of the flagship RDP projects showed very little regard for the immediate environment in many areas such as Bredasdorp and Montagu where floods and heavy rains have inflicted great damage on badly planned RDP houses. Despite criticism from environmental groups of the way in which the government acts upon its social development policy, new directions in global environmental management that placed poverty reduction at the centre of sustainable development by the late 1990s, effectively enables the ANC government to continue with their social development programmes without real environmental considerations (Le Quesne 2000; Steyn 2002; Die Burger 2003; Die Burger 2004).

The unsustainable nature of much social and economic development in the new South Africa is in no small part due to the fact that the country is still a far way from developing a national strategy for sustainable development and a national action plan for the implementation of Agenda 21. Hosting the 2002 World Summit on Sustainable Development ironically did not help to speed up the processes. An important contributing factor for the slow progress made in the promotion of sustainable development in the country is the fact that the local government structures, who are responsible for 
implementing sustainable development processes in the country, have not been included as stakeholders in environmental planning. Consequently, apart from a few metropolitan areas such as Cape Town, Durban and Johannesburg, few local government structures have produced the integrated development plans, which provides the framework for the development role of local governments, required of them in terms of the Municipal Systems Act of 2000 (Rossouw and Wiseman 2004; Republic of South Africa 2002).

The ANC had a slow start where the environment is concerned and were hampered in the first two terms by the enormous negative legacy of the apartheid era. Their greatest contributions to environmental issues between 1994 and 2004, was limited to the development of new environmental legislation, the inclusion of all stakeholders in environmental planning and development, the promotion of the equitable distribution of natural resources and access to resources, and the establishment of transfrontier conservation areas. Important pro-environment initiatives included a ban on the free provision of plastic bags (which drastically reduced plastic pollution overnight), the banning of all-terrain vehicles from ecologically sensitive beaches, the clamping down on over-fishing, the introduction of unleaded petrol and the combating of invasive alien plants. True developments in pollution control only started to follow after an amendment to the National Environmental Management Act in 2003 gave the Department of Environmental Affairs and Tourism greater powers to investigate environmental law violations. Consequently, the Directorate of Regulatory Services for the first time obtained the powers of search and seizure, powers which have greatly improved their effectiveness to the point where they are now commonly referred to in the media as the Green Scorpions (after the elite police unit). Maybe with the help of the Green Scorpions the ANC government will prove to be more effective than their predecessors in protecting and promoting the health and well-being of the South African environment. This is desperately needed if the government wants to realise the environmental rights of the South African citizenry, as expressed in the Bill of Rights (Groenewald 2004; Nell 2004; Macleod 2005).

\section{Conclusion}


This article has explored some of the environmental legacies of the apartheid-era for the new South Africa. In some respects the transition from the old to the new regime mearely meant that someone different were implementing the same or similar environment-related policies in the period after 1994. The ANC government, for example, not only continued with the fragmented approach to governmental environmental management but managed to fragment it even further by assigning provincial and local governments environmental management duties. Likewise the Department of Environmental Affairs and Tourism has changed very little apart from the people who work there and is still a far way from being the strong, centralised government department so greatly needed for constructive environmental management on governmental level. The re-writing of the country's environmental laws did signal a great departure from the apartheid-era, but the (inherited) unwillingness to implement and properly enforce these laws, especially those related to industry remains endemic to governmental environmental management in the country. Only in the new South Africa this lack of enforcement is done in the name of poverty reduction while in the apartheid era it was driven by the need to survive economically in a hostile global environment. And, while the country is now once more a respected member of the global political community, the country is still a far way from implementing sustainable development policies on a national scale, despite the fact that it hosted the World Summit on Sustainable Development in 2002. It is obvious from various policy documents that there is a greater understanding of the importance of sustainable development within government circles today than at the end of the apartheid period, but this understanding without proper governmental action is meaningless.

Though there is a high level of continuity between the old and the new regimes, there are also important differences in the environmental management practices of these two regimes. Probably the most striking and immediately beneficial to some is the massive regeneration projects launched in black and coloured communities situated in both urban and rural communities. The RDP brought houses, sanitation, safe water, electricity and services to millions of formerly disadvantaged South Africans thereby radically improving the natural and human environments in which these communities live. The 
involvement of all the stakeholders in environmental management, with the exception of the all-important local government structures, has also ensured that environmental management processes became more transparent. As did the involvement of local communities in environmental management which contributes a great deal to countering established notions that successful conservation efforts result from limited human interference. In same ways the ANC is bringing South Africans closer to nature by acknowledging the importance of nature in the survival of many rural communities, and by allowing these communities to actively participate in initiatives that impact on their natural and human environments.

\section{Notes}

1. Jan Giliomee Private Document Collection (JGPDC, Stellenbosch, South Africa), Habitat Council: C. van Note, Statement on US enforcement of the Convention on International Trade in Endangered Species, 14.7.1988, pp. 10-12.

\section{References}

ANC. 1992. Ready to Govern: An Introduction to the ANC's Policy Guidelines. Johannesburg: ANC.

ANC. 1994. The Reconstruction and Development Programme. Johannesburg: Umyanyano Publications.

Anon. 1991. Pollution Critical in SA as Perennial Rivers Run Dry. Chamber of Mines Journal, 33(4).

Business Day. 1991. 21 November, p. 5.

Clarke, J. 1991. Back to Earth: South Africa's Environmental Challenges. Johannesburg: Southern Book Publishers. 
Clarke, J. 2002. Coming Back to Earth: South Africa's Changing Environment. Johannesburg: Jacana.

Cock, J. 1991. Going Green at the Grassroots: The Environment as a Political Issue. In: J. Cock and E. Koch, eds. Going Green: People, Politics and the Environment in Southern Africa. Cape Town: Oxford University Press.

Cooper, C. 1992. The Environment and the Poor. South African Institute of Race Relations Fast Facts, 10.

Department of Environmental Affairs and Tourism. 1999. State of the Environment: South Africa 1999. An Overview. Pretoria: DEA\&T.

Department of Environmental Affairs and Tourism. 2005. Clean Air Imbizo: Vaal Triangle to be SA's First Pollution 'Hot Spot'. Media Release, 6 June. Available from: http://www.deat.gov.za/NewsMedia/MedStat/2005Jun6/06062005_2.htm [Accessed 8 June 2005].

Die Burger. 2003. 29 March, p. 1.

Die Burger. 2004. 7 October, p. 1.

Die Volksblad. 1999. 28 October, p. 9.

Durning, A.B. 1990. Apartheid's Environmental Toll. Worldwatch Paper 95. Washington, D.C.: Worldwatch Institute.

Fuggle, R.F. and M.A. Rabie. 1999. Environmental Management in South Africa: Postscript 1999. In: R.F. Fuggle and M.A. Rabie, eds. Environmental Management in South Africa. Cape Town: Juta \& Co. Ltd. 
Glazewski, J.I. 1991. Current and Future Directions in South African Environmental Law. Strategic Review for Southern Africa, 13(1).

Groenewald, Y. 2004. Last Gasp for Mouldy Act. Earthyear, 5.

Koch, E., D. Cooper and H. Coetzee. 1990. Water, Waste and Wildlife: The Politics of Ecology in South Africa. Johannesburg: Penguin Books.

Le Quesne, T. 2000. The Divorce of Environmental and Economic Policy under the First ANC Government, 1994-1999. The South African Journal of Environmental Law and Policy, 7(1).

Macleod, F. 2005. Gutsy Dirt Busters. Mail \& Guardian Online, 26 May. Available from: http://www.mg.co.za/articlePage.aspx?articleid=241737\&area=/insight/insight _national/ [Accessed 19 June 2005].

McDonald, D.A. 1998. Three Steps Forward, Two Steps Back: Ideology and Urban Ecology in South Africa. Review of African Political Economy, 75.

Nell, M. 2004. Greening the parties. Earthyear, 2.

Rabie, M.A. 1994. The Environment Conservation Act and its Implementation. The South African Journal of Environmental Law and Policy, 1(1).

Rabie, M.A. and M.G. Erasmus. 1983. Environmental Law. In: R.F. Fuggle and M.A. Rabie, eds. Environmental Concerns in South Africa: Technical and Legal Perspectives. Cape Town: Juta \& Co. Ltd.

Rabie, M.A. and R.F. Fuggle. 1992. The Rise of Environmental Concern. In: R.F. Fuggle and M.A. Rabie, eds. Environmental Management in South Africa. Cape Town: Juta \& Co. Ltd. 
Rautenbach, P.S. 1972. Toespraak oor Omgewingsbewaring voor die Vereniging vir die Beskerming van die Omgewing, Pretoria, 18 Oktober 1972. Society for the Protection of the Environment Newsletter, 2(4).

Rautenbach, P.S. 1973. The International Status of Environmental Conservation. In: Department of Planning and the Environment. Proceedings of the International Symposium on Planning for Environmental Conservation 4-6.9.1973. Pretoria: DPE.

Republic of South Africa. 1988. Annual report of the Department of Environment Affairs, 1987-1988. RP 114/1988. The Government Printer, Pretoria.

Republic of South Africa. 1992. Building the Foundation for Sustainable Development in South Africa. National Report to the United Nations Conference on Environment and Development (UNCED) to be held in Rio de Janeiro, June 1992. Pretoria: DEA\&T.

Republic of South Africa. 2002. Johannesburg Summit 2002. South Africa: Country Profile. New York: UN.

Rossouw, N. and K. Wiseman. 2004. Learning from the Implementation of Environmental Public Policy Instruments after the First Ten Years of Democracy in South Africa. Impact Assessment and Project Appraisal, 22(2).

Smuts, B. 1995. Green Lessons of Apartheid. African Wildlife, 49(2).

Steyn, P. 2001. Environmental Management in South Africa: Twenty Years of Governmental Response to the Global Challenge, 1972-1992. Historia, 46 (1).

Steyn, P. 2002. Global Environmental Management: An Exploration of the World Summit on Sustainable Development. Journal for Contemporary History, 27(3). 
Steyn, P. and A. Wessels. 2000. The Emergence of New Environmentalism in South Africa, 1972-1992. South African Historical Journal, 42.

The Presidency. 2003. Towards a Ten Year Review: Synthesis Report on Implementation of Government Programmes. Discussion document, Policy Co-Ordination and Advisory Service. Pretoria: Government Communication and Information Service.

The Star. 1972. 10 June, p. 3.

The Weekly Mail. 1989. 29 September - 5 October, p. 5.

Timberlake, L. Africa in Crisis: The Causes, the Cures of Environmental Bankruptcy. New edition. London: Earthscan.

Tyson, P.D., F.J. Kruger and C.W. Louw. 1988. Atmospheric Pollution and its Implications in the Eastern Transvaal Highveld. South African National Scientific Programmes report 150. Pretoria: CSIR.

United Nations. 1972. Report of the United Nations Conference on the Human Environment Stockholm, 5-16 June 1972. New York: UN.

Van der Berg, S. 1985. An Overview of Development in the Homelands. In: H. Giliomee and L. Schlemmer, eds. Up Against the Fences: Poverty, Passes and Privilege in South Africa. Cape Town: David Philip.

Van der Merwe, I. 1992. The Summit of '92. Conserva, 7(5).

Van Eeden, M. 1991. Besoedelde Rivier Wek Kommer. Prisma, 6(3). 
Wiley, J. 1986. Suid-Afrika se Rol en Betrokkenheid by Internasionale Omgewingsbewaring. C.R. Swart Lecture no 19. Bloemfontein: University of the Orange Free State.

Wisner, B. 1995. The Reconstruction of Environmental Rights in Urban South Africa. Human Ecology, 23(2).

Wynberg, R.P. 1993. Exploring the Earth Summit. Findings of the Rio United Nations Conference on Environment and Development: Implications for South Africa. M.Phil. Dissertation, University of Cape Town. 